\title{
MĘCZEŃSTWO JAKO PARADOKSALNE ŚWIADECTWO ŻYCIA W AKTACH I PASJACH MĘCZENNIKÓW
}

Wyjątkowość Akt męczenników (Acta Martyrum) i Pasji Męczenników (Passiones Martyrum) wśród innych gatunków literatury wczesnochrześcijańskiej polega między innymi na tym, że nie są one w swojej istocie owocem teoretycznych rozważań nad Objawieniem, lecz za punkt wyjścia ex definitione

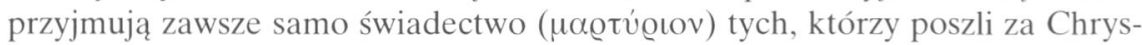

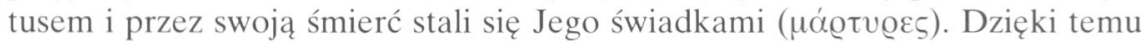
stanowią one nie tylko cenne, komplementarne źródło w poznawaniu chrześcijańskich koncepcji teologicznych pierwszych wieków, ale dają nam często bezpośredni obraz tego, jak były one przez samych chrześcijan przeżywane i jakie znaczenie dla nich miały w ich osobistych wyborach ${ }^{1}$.

W niniejszym artykule nie będę się zajmował kwestią autentyczności przekazu. Interesują mnie Akta i Pasje Męczenników potraktowane przede wszystkim jako tekst teologiczny, jako pomnik myśli i rozważań nad Objawieniem zrodzonych z konfrontacji ze światem pogańskim, którego cokołem jest stojące zawsze u początku przekazu żywe doświadczenie. Ekstremalne okoliczności ukazują bowiem to, co świadkowie-męczennicy myślą o Bogu i o świecie, a przede wszystkim, jak postrzegają siebie samych w świetle dokonanego wyboru.

W pochodzącym z 2. poł. II wieku Męczeństwie Polikarpa ${ }^{2}$, biskup małoazjatyckiej Smyrny, na trzy dni przed pojmaniem ma podczas modlitwy prorocze widzenie (5), w którym jego poduszka płonie. Widzenie to Polikarp interpretuje krótko i esencjonalnie: „Trzeba, ażebym spłonął żywcem!”’3. Rzeczywiście, po trzech dniach biskup Smyrny zostaje schwytany i skazany na spalenie na stosie. Dochodzi do egzekucji (15-16). Stos zostaje podpalony, jednak płomienie nie wyrządzają Polikarpowi żadnej krzywdy. I chociaż ostatecznie biskup męczennik kończy życie w chwilę po przejściu próby ognia przebity mieczem,

${ }^{1}$ Por. B. Dehandschutter, Le Martyre de Polycarpe et le développement de la conception du martyre au deuxième siècle, StPatr $17 / 2$ (1982) 659.

${ }^{2}$ Por. wyd. P.Th. Camelot, Martyrium Polycarpi, SCh 10, Paris 1969, 210-239.

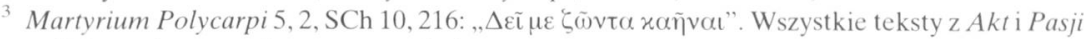
Męczenników w tłumaczeniu autora artykułu. 
to sens jego proroczych słów w sposób oczywisty nie ogranicza się do faktu, że jego ciało, na chwilę przed śmiercią, zostaje w cudowny, niewytłumaczalny sposób zachowane od ognia. Żeby móc właściwie zinterpretować proroczą wizję Polikarpa i jego cudowne ocalenie z płomieni, trzeba się cofnąć do rozdz. 11, w którym to przesłuchiwany Polikarp, w odpowiedzi na groźby prokonsula, że ów wyda go na pastwę płomieni, odpowiada:

„Grozisz mi ogniem, który płonie tylko przez krótki czas i po chwili gaśnie. Nie znasz bowiem ognia przyszłego sądu i wiecznej kary, zachowanego dla bezbożników"

„Po chwili gaśnie”, ponieważ męczennik głęboko wierzy, że, śmierć jest dla niego przede wszystkim wejściem w życie wieczne, nie tylko duszy, ale też i ciała (14).

Podobne przeciwstawienie ognia wiecznego i ognia doczesnego, oraz błogosławieństwo tego ostatniego spotykamy w pochodzącym także z 2. poł. II wieku chrześcijańskim dziełku Do Diogneta:

„Gdy przestraszysz się śmierci rzeczywistej przeznaczonej dla skazanych na ogień wieczny, który do końca będzie karał tych, którzy zostali mu wydani, wtedy będziesz podziwiał i uważał za szczęśliwych ludzi cierpiących ten ogień [na ziemi], kiedy ów [wieczny] ogień poznasz"

Narzuca się zatem interpretacja, że cudowne ocalenie Polikarpa od działania płomieni ma głęboki sens alegoryczny i wyraża wiarę w to, że nad tym, który poszedł za Chrystusem, śmierć nie ma już żadnego panowania oraz że życie wieczne jest jego udziałem już na tym świecie (zob. np. 1J 3, 14; 1Kor 15, 55; 2 Kor 6, 9).

Bezpośrednio do Męczeństwa Polikarpa nawiązuje ${ }^{6}$ późniejsze Męczeństwo Pioniusza $a^{7}$ skazanie Pioniusza, na spalenie żywcem (również $\zeta \tilde{\omega} v \tau \alpha$ xã̃val) ma podobnie alegoryczne znaczenie:

„O wieńcu chwały [jaki zdobył] zaświadczyło też jego ciało. Albowiem, gdy zgasł ogień, ujrzeliśmy my, którzyśmy tam byli, ciało pięknego atlety u szczytu sił. Uszy

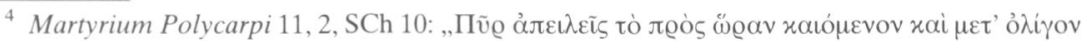

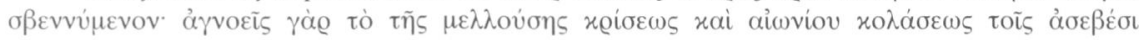

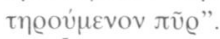

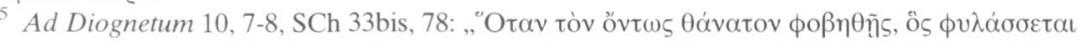

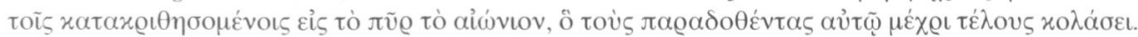

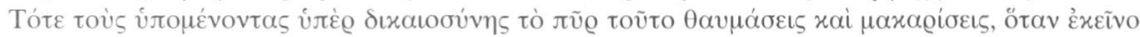

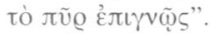

6 Por. M. Simonetti, Studi agiografici, Roma 1955, 36.

7 Por. H. Musurillo, Acts of the Christian Martyrs, Oxford 1972, 136-167. Śmierć Pioniusza miała miejsce 12 marca 250 r., zaś tekst Martyrium Polycarpi został napisany niedługo po samych wydarzeniach. 
jego nie były zniekształcone, włosy na jego głowie były ułożone, a broda jego była niczym pierwszy kwitnący młodzieńczy zarost. Rozjaśniła się także jego twarz cud łaski"8.

W tym dokumencie mamy do czynienia jakby z rozwinięciem tego, co znajdujemy w Męczeństwie Polikarpa. Pioniusz nie tylko jest oszczędzony przez płomienie, ale już w ogniu jego ciało staje się ciałem zmartwychwstałym, idealną ikoną Adama, namalowaną zgodnie z helleńskimi wyobrażeniami, ciałem pięknego efeba: „Jeśli zaś chodzi o wiek, to Adam był młodzieńcem”9.

W obu więc przypadkach ,spalenie żywcem” ( $\zeta \tilde{\omega} v \tau \alpha \varkappa \alpha \tilde{\eta} v \alpha$ l), termin techniczny, ma sens alegoryczny i wskazuje na to, że śmierć nie ma nad świadkami Chrystusa, już w doczesności, żadnego panowania. Stanowi ilustrację słów z I Listu św. Jana: „Wiemy, że przeszliśmy ze śmierci do życia”10, oraz współbrzmi ze świadomością apologetów - porte-paroles wczesnego chrześcijaństwa - takich jak Minucjusz Feliks, który w swoim Oktawiuszu pisze:

„Nas, którzy jesteśmy cisi, skromni i dzięki bożej hojności wolni od trosk, ożywia nadzieja przyszłego szczęścia i wiara w już tu widoczną obecność bożego majestatu. Już teraz bowiem przeżywamy radość zmartwychwstania, rozpamiętując to, co nastąpi" 11 .

Perspektywa męczennika zostaje zredukowana do prostego wyboru między życiem a śmiercią, a raczej między tym, co on uznał za prawdziwe życie i czego gwarantem jest zmartwychwstały Chrystus, a tym, co uznał za prawdziwą śmierć - wyparciem się tegoż Chrystusa, który jest samym Życiem (J 11, 25:

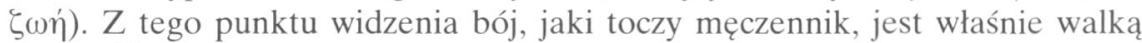
o życie ${ }^{12}$ i ucieczką przed śmiercią, a nie jej poszukiwaniem, jak mogło się wydawać poganom ${ }^{13}$.

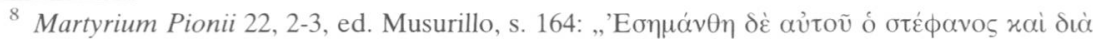

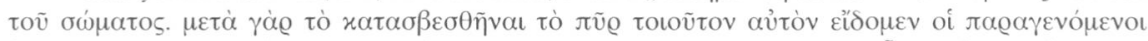

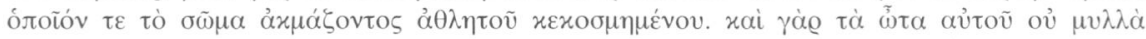

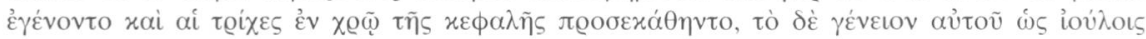

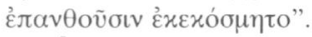

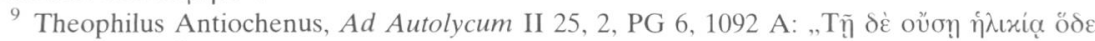

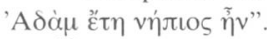

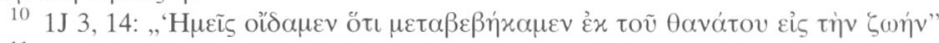

11 Octavius 38, 4, CSEL 2, 54: „quieti, modesti, Dei nostri liberalitate securi spem futurae felicitatis fide praesentis eius maiestatis animamus. Sic et beati resurgimus et futuri contemplatione iam vivimus".

${ }^{12}$ Por. Martyrium Julii Veterani 3, 5, ed. Musurillo, s. 262: „Maksimus powiedział: «Współczuję ci, dlatego radzę - tym bardziej złóż ofiarę i żyj razem z nami». Juliusz odpowiedział: «Jeżeli będę żył z wami, będzie to dla mnie śmiercią. Jeśli zaś umrę przed obliczem Pana, będę żył na wieki»".

${ }^{13}$ Por. Martyrium Pionii 20, 5, ed. Musurillo, s. 162: „Zapytano go: «Tak ci się spieszy do śmierci»? On zaś odrzekł: «Nie do śmierci, ale do życia». Prokonsul Kwintylian rzekł: «Ten twój 
O jakie jednak życie zabiega męczennik, jakiej prawdzie daje on świadectwo? Jak je sobie wyobraża i jak, przede wszystkim, ma się ono do życia doczesnego, z którym się właśnie w tak dramatycznych okolicznościach rozstaje? Odpowiedź, jakiej na kartach Akt i Pasji Męczenników ${ }^{14}$ udzielają sami męczennicy jest zaskakująca: wydaje się, że świadkom Chrystusa chodzi o to życie, z którym w oczach pogan właśnie się rozstają, i czynią oni wszystko, co w ich mocy, żeby je zachować.

Jedną z pierwszych rzeczy, które natychmiast rzucają się w oczy czytającemu Akta i Pasje Męczenników, jest mnóstwo antynomii, kształtujących i określających relację między „Prawdą Objawioną”, której rzecznikiem jest świadekmęczennik, a reprezentowanym najczęściej przez namiestnika pogańskim światem. Oto obłęd okazuje się prawdziwą pobożnością ${ }^{15}$; jedna godzina męki równoważy wieczną karę ${ }^{16}$; ogień, którym są paleni męczennicy, jest zimny ${ }^{17}$; wreszcie śmierć zostaje nazwana wprost życiem ${ }^{18}$. Antynomie pojawiają się w kontekście męczeńskiej śmierci świadków Chrystusa w sposób niejako spontaniczny i wydają się wyrażać radykalną rozbieżność między życiem dla tego świata a życiem w królestwie niebieskim ${ }^{19}$.

Wśród tych antynomii, ukazujących pozornie (jak dalej zobaczymy) nieprzekraczalną przepaść między dwiema wizjami rzeczywistości, pojawia się jednak figura zaskakująca. W sytuacji, gdzie wydaje się, że już nic nie łączy antagonistów, a wszystko dzieli, w morzu kontrowersji, obie strony dochodzą do dziwnego i paradoksalnego porozumienia. W pewnym momencie bowiem antynomiczne dyskursy obu stron pokrywają się. Tam, gdzie spodziewamy się kolejnej kontrowersji, nagle zapanowuje zgoda.

zapał, żeby umrzeć, nie jest niczym niezwykłym. Gladiatorzy, walcząc ze zwierzętami za niewielką ilość srebra, też mają śmierć w pogardzie. I ty jesteś kimś takim. Jeśli jednak tak spieszno ci umrzeć, będziesz spalony żywcem»”; i wcześniej (5, 3, ed. Musurillo, s. 142): „To wszystko jest dobre i bynajmniej nie uciekamy od tego, dlatego że pragniemy śmierci i nienawidzimy dzieł Bożych. Odrzucamy to ze względu na wyższość innych dóbr, jako zastawioną na nas pułapkę".

14 Por. Martyrium Polycarpi; Martyrium Pionii; Acta Carpi, Papyli et Agathonicae.

15 Por. Martyrium Agapae, Irenae et Chionis 6, 2, ed. Musurillo, s. 290: „Dulcitius rzekł do niej: «Jeszcze trzymasz się tego obłędu (ả゙ovoía)»? Irena odpowiedziała: «Nie obłędu, ale pobożności

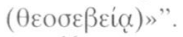

${ }_{17}$ Por. przypis następny.

17 Por. Martyrium Polycarpi 2, 3, SCh 10, 178: „Przez jedną godzinę wykupując się z wiecznej kary; ogień zaś był dla nich zimny".

18 Por. Martyrium Pionii 20, 5, ed. Musurillo, s. 162: „Zapytano go: «Dlaczego spieszy ci się do

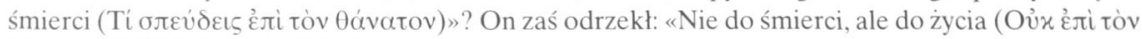

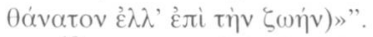

19 Por. 2Kor 6, 9-10: „Wśród czci i pohańbienia, przez dobrą sławę i zniesławienie, uchodzący za oszustów, a przecież prawdomówni, niby nieznani, a przecież dobrze znani, niby umierający, a oto żyjemy, jakby karceni, lecz nie uśmiercani, jakby smutni, lecz zawsze radośni, jakby ubodzy, a jednak wzbogacający wielu, jako ci, którzy nic nie mają, a posiadają wszystko"; zob. także $A d$ Diognetum 5, 8-16. 
W łacińskiej recenzji ${ }^{20}$ Akt Karposa, Papilosa i Agatoniki, opowiadających o świadectwie, jakie za panowania cesarza Marka Aureliusza dali w Pergamonie spaleni na stosie z polecenia prokonsula Flaviusa Optimusa wymienieni w tytule męczennicy, czytamy:

„Prokonsul powiedział: «Miej litość dla siebie samego» (miserere tibimetipsi) Karpos odpowiedział: «Mam litość dla siebie samego (misereor mihimetipsi), jeśli wybieram to, co lepsze»"21.

Podobny przykład znajdujemy w innym lacińskim tekście, Męczeństwie Ireneusza $a^{22}$. Biskup tego imienia złożył je w mieście Sirmium w Panonii w czasie prześladowań za Dioklecjana ${ }^{23}$. Namiestnik Panonii, Probus stara się go przekonać, mówiąc:

„„Uniknij śmierci (lucrare mortem). Wystarczy ci już mąk, które wycierpiałeś» Ireneusz odpowiedział: "Cały czas unikam śmierci (lucror continuo mortem), kiedy znoszę cierpienia, które - jak sądzisz - mi zadajesz, a których ja nie czuję, bo otrzymuję od Boga życie wieczne»"24.

Ta sama figura występuje także w Aktach Fileasa ${ }^{25}$. Fileas, biskup egipskiego miasta Thmuis ${ }^{26}$, poniósł śmierć męczeńską w $306 \mathrm{r}^{27} \mathrm{z}$ wyroku prokonsula Egiptu Kulcianusa ${ }^{28}$. Po wartkiej wymianie krótkich zdań na temat tożsamości ciała doczesnego i ciała zmartwychwstałego (będę ją jeszcze w tym artykule analizował) czytamy:

${ }^{20}$ Tekst akt dotarł do nas w dwóch recenzjach: greckiej i łacińskiej. Recenzje różnią się od siebie w wielu szczegółach. Uważa się jednak, że recenzja grecka jest bliższa oryginalnej wersji akt. Największe różnice dotyczą osoby Agatoniki. W greckiej recenzji Agatonika, stojąca w tłumie gapiów, poruszona męczeńską śmiercią Karposa i Papilosa, wyznawszy wiarę rzuca się w ogień. W łacińskiej jest od początku towarzyszką dwóch męczenników. Interesującej nas wymiany zdań brak w recenzji greckiej; por. Atti e Passioni dei Martiri, Milano 1987, 34.

${ }^{21}$ Acta Carpi, Papyli et Agathonicae 2, 3, ed. Musurillo, s. 30: „Proconsul dixit: Miserere tibimetipsi. Carpus respondit: Misereor mihimetipsi, si eligero meliora".

22 Por. Passio S. Irenaei episcopi Sirmiensis, ed. Musurillo, s. 294-301.

${ }^{23}$ H. Musurillo (s. XLIII) datuje Męczeństwo Ireneusza na wiosnę 304 r. po wydaniu przez Dioklecjana czwartego edyktu.

24 Passio S. Irenaei episcopi Sirmiensis 4, 4, ed. Musurillo, S. 296: „Probus dixit: «Lucrare mortem. Iam tibi sufficiant quae tolerasti tormenta». Irenaeus respondit: «Lucror continuo mortem quando per eas quas mihi putas inferre poenas, quas ego non sentio, propter Deum accipio vitam aeternam»".

${ }^{25}$ Akta Fileasa dotarły do nas w trzech recenzjach: 2 greckich i 1 lacińskiej; cytowane w tym artykule fragmenty pochodzą z jednej z greckich recenzji Papyrus Bodmer XX, ed. G. Lanata, w: Atti e Passioni dei Martiri, s. 316-336.

${ }^{26}$ Wspominają o nim Euzebiusz z Cezarei w Historia Ecclesiastica VIII 9, 6-8 oraz Hieronim w De viris illustribus 78 .

27 Por. Atti e Passioni dei Martiri, s. 250.

28 Clodius Culcianus, prefekt Egiptu (praefectus Aegypti) w latach 303-306, przyjaciel Maksymina Dai. Kulcianus wsławił się wielką gorliwością w prześladowaniu chrześcijan w Egipcie. Wspomina o nim Euzebiusz z Cezarei (HE IX 11, 4); zob. też PLRE I 233-234. 
„Kulcianus rzekł: «Oszczędź siebie i wszystkich, którzy są twoi. Złóż ofiarę!» ( kich, którzy należą do mnie ( $\mu \circ)$ nie składam ofiary»" $(6,12-16)^{29}$.

Na pierwszy rzut oka mamy tu do czynienia ze zwykłym przedrzeźnianiem się, formą dialogu często spotykaną w Aktach i Pasjach Męczenników - męczennik, dostrzegający beznadziejność i bezsensowność spierania się z namiestnikiem o prawdę, czekając na bliskie rozstrzygnięcie drwi sobie w ten sposób z gróźb i zachęt przedstawiciela ,tego świata”.

Jeżeli jednak przyjrzymy się wybranym fragmentom nieco uważniej, dostrzeżemy, że odpowiedź, jakiej udziela męczennik, stanowi sedno jego credo. Słowa namiestnika, będące par excellence słowami „tego świata” (miserere

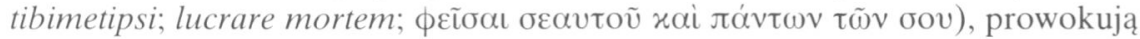
męczennika do ponownego samookreślenia. Męczennik nie decyduje się jednak na konfrontację. Przeciwnie, powtarza prośbę namiestnika, wskazując właśnie na swój wybór i swoje postępowanie jako pozytywną na nią odpowiedź i jako na pełną jej realizację. Widoczna jest troska o literalność tego powtórzenia (miserere tibimetipsi i misereor mihimetipsi, lucrare mortem i lucror

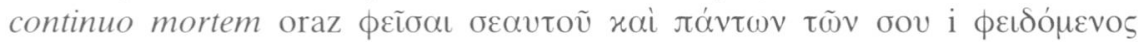

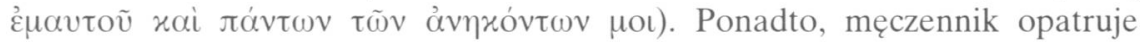
owo nawiązanie komentarzem, który uzasadnia jego postępowanie. Uzasadnienie ma charakter pozytywny. Nie usuwa bowiem sensu słów namiestnika, lecz nadaje im głębszą, pełniejszą perspektywę (,mam litość dla siebie samego" - ,jeśli wybieram to, co lepsze”; ,cały czas unikam śmierci” - „otrzymuję od Boga życie wieczne”; , oszczędzając siebie i wszystkich, które należą do mnie” „nie składam ofiary”).

A zatem, paradoksalnie, w oczach męczennika nie ma między stronami jakiejś zasadniczej rozbieżności. Przeciwnie, to właśnie jego postawa nadaje dopiero słowom namiestnika sens i to on realizuje zawarty w nich postulat miłości samego siebie i mocnego trzymania się życia. Jedyna i zarazem podstawowa różnica polegałaby zatem na drodze, jaka do tego celu prowadzi, i miałaby charakter raczej „techniczny” niż merytoryczny.

To, że nie jest to jedynie szermierka słowna i przedrzeźnianie przeciwnika, ale chodzi o samą istotę rzeczy oraz o figurę myślową obecną w świadomości starożytnych chrześcijan, staje się jasne, gdy przyjrzymy się wymianie zdań między prezbiterem Pioniuszem a kupcami z agory w Męczeństwie Pioniusza:

\footnotetext{
29 Papyrus Bodmer XX 6, 12-16, ed. Lanata, s. 322:

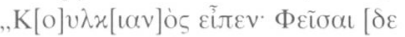

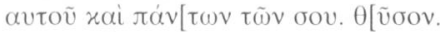

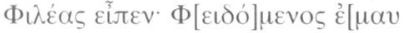

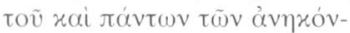

$\tau \omega v$ uot, ov่ $\theta \dot{\omega} \omega "$.
} 
„Wnet przystąpiło do nich kilku kupców z agory, którzy razem z Polemonem tymi słowami błagali Pioniusza: «Posłuchaj nas, Pioniuszu. Kochamy cię i ze wszech

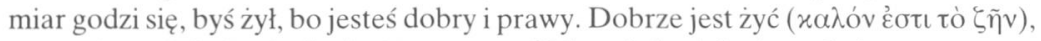

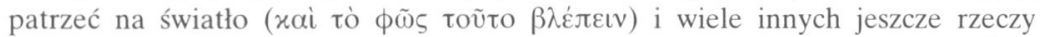
[mówili]». On zaś im odpowiedział: «I ja twierdzę, że dobrze jest żyć ( $x \alpha \jmath \gamma \omega \dot{~}$

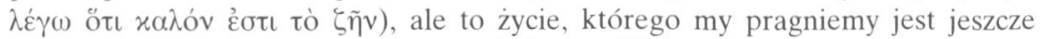

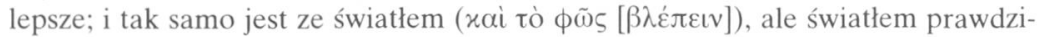
wym. To wszystko jest dobre i bynajmniej nie uciekamy od tego dlatego, że pragniemy śmierci i nienawidzimy dzieł Bożych. Odrzucamy to ze względu na wyższość innych dóbr, jako zastawioną na nas pułapkę»" 30 .

Także Pioniusz nie przeciwstawia dążeń pogan swoim dążeniom, ale stawia je na tej samej płaszczyźnie. Również tutaj widoczna jest troska o dosłowne

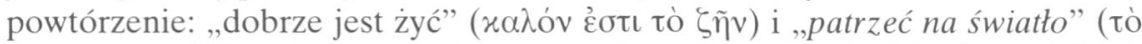

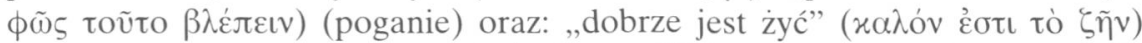

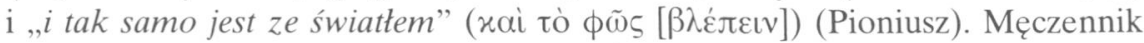
stwierdza wprost, że to, do czego nakłaniają go poganie, jest dobre, on sam zaś,

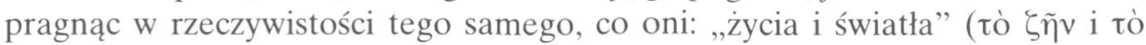

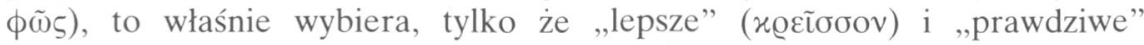

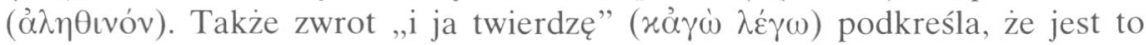
świadoma figura i że Pioniusz wie dobrze, co mówi.

Jak jednak owo przyszłe życie, za którym opowiadają się męczennicy, ma się do życia doczesnego? Jeżeli ciało (gr. oá@६, łac. caro) jest budulcem stanowiącym życie doczesne, z jakiego budulca będzie się składało ciało zmartwychwstałe? Przecież to, co wybierają męczennicy jest właśnie zagładą całej cielesnej doczesności: męczennicy spodziewają się zapewne jakiegoś zupełnie innego życia w obiecanym przez ich Boga ,przyszłym świecie”, należącego do wymiaru duchowego i nijak mającego się do życia ziemskiego, z którym właśnie się rozstają.

W głównym nurcie chrześcijaństwa (w przeciwieństwie do takich prądów, jak np. doketyzm i gnostycyzm) nie było zasadniczych wątpliwości co do tego, że zmartwychwstanie będzie miało wymiar cielesny, a zmartwychwstałe ciało będzie, choć przemienione, zasadniczo tożsame $\mathrm{z}$ poddanym śmierci ciałem doczesnym $^{31}$. Wiara $w$ zmartwychwstanie ciała jako materii konstytuującej człowieka ( $\sigma \alpha ́ \varrho \xi)$, tożsamego z ciałem doczesnym, znajduje swój wyraz także

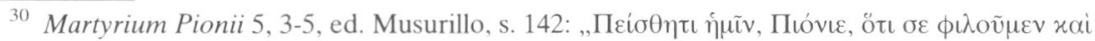

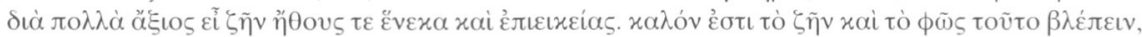

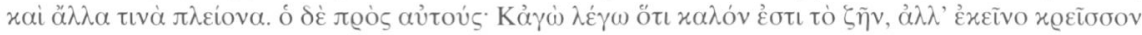

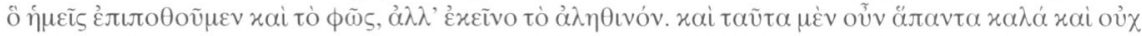

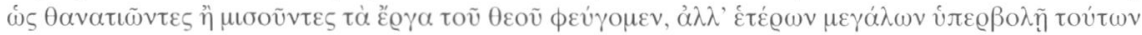

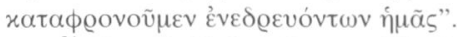

31 Por. C. Walker Bynum, The Resurrection of the Body in Western Christianity (200-1336), New York 1995, 26. 
Kiedy Fileas odpowiada Kulcianusowi, jakich ofiar wymaga Bóg chrześcijan, namiestnik sarkastycznie (1os. l.mn.) pyta, czy Fileas troszczy się tutaj jedynie o duszę. Dla pragmatyka Kulcianusa, widzącego najwidoczniej w doczesnym ocaleniu ciała kres nadziei człowieka - w przeciwnym razie pytanie o troskę duszy nie miałoby tak deprecjonującego tonu - bądź też jako neoplatonika z jednej strony deprecjonującego element cielesny, z drugiej zaś pogardzającego podobnie do Marka Aureliusza upartą i bezrozumną, z jego punktu widzenia, troską chrześcijan o dusze ${ }^{34}$ - jest aberracją sama myśl o tym, że przedmiotem troski Fileasa jest obok duszy także i ciało. Przecież cała postawa Fileasa temu przeczy. Oto przed jego obliczem stoi człowiek, który już cztery razy był wzywany przed oblicze władzy rzymskiej i za każdym razem jego ciało było poddawane okrutnym torturom $(1,5-2,4)$. A jednak w pytaniu Kulcianusa słychać niepewność. Skoro jest dla niego czymś oczywistym, że Fileas nie położył swojej nadziei w ciele, to dlaczego pyta się Fileasa, czy nie troszczy się także o ciało? Słyszał zapewne o wyznawanej przez chrześcijan wierze w zmartwychwstanie. Być może jednak coś go wcześniej w postawie Fileasa zaintrygowało. Może coś, co nie pozwalało w nim widzieć jedynie mającego świat w pogardzie szalonego fanatyka. Może wcześniej Fileas udzielił mu odpowiedzi podobnej do tej, której udzielił poganom Pioniusz: „To wszystko jest dobre i bynajmniej nie uciekamy od tego dlatego, że pragniemy śmierci i nienawidzimy dzieł Bożych"? Nie wiemy. Wiadomo jednak, że tej wymiany zdań nie można uznać jedynie za grę słów - ,giochi di parole” - jak tego chce G.A.A. Kortekaas ${ }^{35}$.

Dalszy przebieg dialogu pogłębia niepokój Kulcianusa. Widzimy jak w swoim badaniu zagłębia się coraz bardziej w „,cielesność”. Upewnia się,

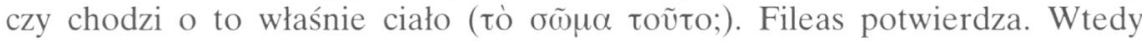

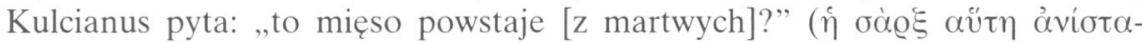
$\tau \alpha$;). Po czym ponownie, nie czekając na odpowiedź Fileasa, zdumiony ( $\alpha \alpha \alpha \tau \lambda \eta \sigma \sigma o ́ \mu \varepsilon v o \zeta)$ - autor akt nie omieszkał tego podkreślić - pyta z niedo-

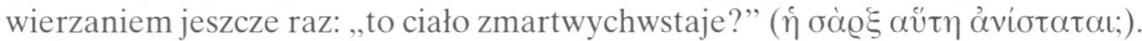
Fileas odpowiada twierdząco. Ani w drugiej wersji greckiej ${ }^{36}$, pierwotniejszej ${ }^{37}$ od przytaczanej w artykule i pozbawionej licznych dodatków i udoskonaleń retorycznych obecnych $\mathrm{w}$ cytowanej recenzji, ani w wersji łacińskiej $\mathrm{akt}^{38}$, również reprezentującej wcześniejsze stadium tekstu, nie znajdujemy tej

${ }^{34}$ Por. Marcus Aurelius, Meditationes 11, 3, tłum. M. Reiter: Marek Aurelisz, Rozmyślania, Warszawa 1988, 131: „Jakaż to jest dusza gotowa, gdy zajdzie już taka potrzeba odłączenia się od ciała, albo zgasnąć, albo rozproszyć się, albo dalej trwać! Byle tylko ta gotowość szła z własnego postanowienia, nie przez prosty upór, jak u chrześcijan, ale w sposób rozumny i poważny i tak, by innego mogła przekonać bez maski tragicznej”.

35 Por. wstęp do Acta Phileae w: Atti e Passioni dei Martiri, s. 265

36 Por. Papyrus Chester Beatty XV,w: Atti e Passioni dei Martiri, s. 281-315.

37 Por. tamże, s. 264-265.

38 Por. tamże, s. 280-314. 
„podwójnej” reakcji Kulcianusa. Oznacza to, że redaktor cytowanej pełniej rozwijającej i rozbudowującej także ten wątek recenzji ${ }^{39}$ świadomie dodał tę reakcję Kulcianusa, tak by jeszcze bardziej uwypuklić paradoks żywionej przez Fileasa nadziei na zmartwychwstanie „mięsa”.

Przyjrzyjmy się raz jeszcze ostatniej części dialogu. Widzimy, że Kulcianus ma najpierw problemy ze zrozumieniem, że Fileasowi chodzi nie tylko o duszę, ale także o ciało, potem zaś, z przyjęciem do wiadomości, że chodzi właśnie o to

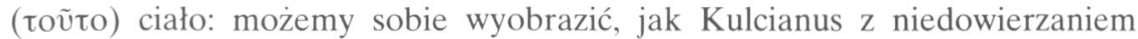
chwyta się sugestywnie za nadgarstek. Fileas odpowiada lakonicznie: „Tak” (Nai). Po tej odpowiedzi, namiestnik chce się jeszcze dodatkowo upewnić, czy Fileasowi naprawdę chodzi o to „mięso" ( $\sigma a ́ \varrho \xi)$. Znamienne jest to, że Kulcianus opatruje $\sigma \alpha \dot{\varrho} \xi$ rodzajnikiem określonym i zaimkiem wskazującym ( $\dot{\eta} \sigma \alpha \grave{g} \xi$

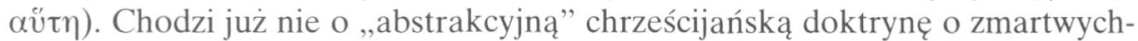
wstaniu ciała, ale o los tego konkretnego „mięsa”. Ważne jest także zastąpienie przez Kulcianusa wyrazu $\sigma \tilde{\omega} \mu \alpha$ słowem $\sigma \alpha \dot{\alpha} \xi^{40}$. Analogiczna zamiana ma miejsce w recenzji łacińskiej, gdzie Kulcianus najpierw pyta o corpus: At corporis huius? $(2,3)$, a następnie precyzuje: Caro haec resurgit? $(2,4)$.

Powyższy fragment unaocznia nam, jak wielkim paradoksem jest nadzieja zmartwychwstania doczesnego ciała (chciałoby się za Kulcianusem powiedzieć: „mięsa”) i jak wielki mieli poganie problem ze zrozumieniem tożsamości ciała zmartwychwstałego $\mathrm{z}$ ciałem doczesnym ${ }^{41}$.

Fileas nie porzuca zatem nadziei związanych z tym światem. Przeciwnie, właśnie nadzieja na życie w Chrystusie, które On daje światu (J 6, 33; 6, 51), w zmartwychwstałym ciele, sprawia, że nikt i nic nie jest w stanie go z obranej drogi zawrócić. Wierzy, że ocala siebie samego i wszystkich tych, którzy mu zostali powierzeni, nie pozostawiając Kulcianusowi żadnych wątpliwości co do tego, że jego nadzieje wiążą się właśnie z tym ciałem.

Reasumując: dyskursy obu stron (pogańskiej i chrześcijańskiej), których rozbieżność do tej pory znajdowała wyraz w jak najjaskrawszych antynomiach, niespodziewanie pokrywają się. Strona pogańska występuje z pewną propozycją, która charakteryzuje jej punkt widzenia. Próbuje przekonać chrześcijan do tego, w czego dobro szczerze wierzy i co uznaje za właściwy, także z eschatologicznego punktu widzenia wybór („Posłuchaj nas, Pioniuszu. Kochamy cię i godzi się, byś żył, bo jesteś dobry i prawy"). Męczennicy jednak

${ }^{39}$ Por. tamże, s. 264-265.

${ }^{40}$ Por. G.W.H. Lampe, Patristic Greek Lexicon, Oxford 1978, s. 1224, 1362.

41 W Oktawiuszu Minucjusza Feliksa (11, 7, CSEL 2, 15-16) poganin Cecyliusz pyta: „Chciałbym się jeszcze dowiedzieć, czy zmartwychwstanie nastąpi w ciele, a [jeśli tak], to w jakim: w tym samym, czy w odmienionym? [Nastąpi] poza ciałem? Ono przecież, na ile wiem, nie jest ani umysłem, ani duszą, ani życiem. [Czyżby] w tym samym ciele? Ale przecież ono już się dawno rozpadło. Może więc jeszcze w innym ciele? Jeśli jednak tak, to są to narodziny nowego człowieka, nie zaś odrodzenie się dawnego". 
nie wchodzą w polemikę $\mathrm{z}$ argumentami strony pogańskiej, jak to ma miejsce gdzie indziej, ale przyjmują je jako swoje. Dopiero chrześcijańska opcja nadaje im sens i ukazuje perspektywę pełnej realizacji. Męczennicy, starannie powtarzając wyrazy, ukazują, że ich wybór jest najwłaściwszym ukierunkowaniem wspólnych dla obu stron pragnień. Troska o dosłowność powtórzenia dobitnie wskazuje na to, że obie strony maja w rzeczywistości na uwadze to samo pragną oddać Bogu należną Mu cześć ${ }^{42}$ i zachować życie, a jedyna, ale jednocześnie fundamentalna i rozstrzygająca różnica polega na odmiennym rozumieniu tego, co prowadzi do urzeczywistnienia owego upragnionego dobra.

Horyzont nadziei pogan, przeciwstawiony horyzontowi nadziei chrześcijańskiej, zredukowany w Aktach i Pasjach Męczenników do trzymania się życia za wszelką cenę - z punktu widzenia męczenników, paradoksalnie, właśnie za cenę życia - jawi się więc tutaj jako swoista praeparatio evangelica. Pragnienie ocalenia cielesnego życia na tym świecie jest nie tyle pokusą, co propedeutyką wiary w zmartwychwstanie. W tych ekstremalnych okolicznościach, kiedy pokusa bezwzględnego potępienia wszystkiego, co wiąże się z odbierającym właśnie życie pogaństwem, jest olbrzymia, zostaje ukazana wielka prawda Objawienia, że Bóg ukochał (ten) świat (por. J 3, 16), że Chrystus przyszedł (ten) świat ocalić (por. J 3, 14; J 4, 42) i dać mu utracone życie (por. J 6, 51), czego żywymi i namacalnymi świadkami są męczennicy.

Jest to figura w swojej istocie głęboko biblijna. Jasno występuje chociażby w czwartym rozdziale Ewangelii wg św. Jana, gdzie Jezus rozmawia przy studni z Samarytanką. Kobieta przychodzi do studni po wodę, potrzebną w gospodarstwie domowym, a nade wszystko gaszącą pragnienie. Spotyka przy niej Jezusa, od którego dowiaduje się o istnieniu wody żywej, która zaspokaja pragnienie na wieczność. Przygotowaniem na przyjęcie Boga jest naturalne pragnienie wody, i to do niego odwołuje się Jezus, kiedy mówi o wodzie, którą sam może dać, a która jest potężną amplifikacją obfitości wody ze studni: „Woda, którą Ja mu dam, stanie się w nim źródłem wody wytryskającej ku życiu wiecznemu" (J 4, 14). Tak też, dosłownie, rozumie jego zapowiedź kobieta samarytańska, mówiąc: „Daj mi tej wody, abym już nie pragnęła i nie przychodziła tu czerpać” $(\mathrm{J} 4,15)$.

Niektórzy badacze ${ }^{43}$ uważają, że ta figura ma za zadanie przede wszystkim unaocznić i udramatyzować dysproporcję między ludzkim i boskim sposobem patrzenia, i zwracają uwagę przede wszystkim na różnicę, jaka między tymi dwiema perspektywami zachodzi. W rzeczywistości jednak figura ta posiada jeszcze jeden fundamentalny sens. Oto pragnienie wody, wina czy głód chleba przede wszystkim naprowadzają na Boga, a nie od Niego oddzielają. Na kartach całego Nowego Testamentu właśnie to, co najbardziej ludzkie i „światowe”:

${ }^{42}$ Por. także Martyrium Polycarpi 9, 2; Martyrium Julii Veterani 3, 3; Martyrium Irenaei episcopi Sirmiensis 2, 4; Martyrium Crispinae 1, 6.

${ }^{43}$ Np. A. Paciorek, Ewangelia św. Jana, Lublin 2000, 35-38; A. Wilder, Early christian rhetoric, Harvard 1971, 48-49. 
woda, wino i chleb - ,żywioły kosmosu”, a nade wszystko samo ciało, wskazują na chrześcijańskie telos, na Zmartwychwstałego, na samego Boga.

W Aktach i Pasjach Męczenników znajduje wyraz także i ten wymiar Objawienia. Wbrew temu, czego moglibyśmy się spodziewać, zachłanność odbierającego męczennikom życie świata zostaje wykorzystana do głoszenia dobrej nowiny o przywróconym życiu. Miłość do świata i umiłowanie życia (tak duszy jak i ciała), znajdują w oczach męczenników spełnienie dopiero w zmartwychwstałym Chrystusie. W tym świetle męczennicy stają się świadkami Życia, które się w nich objawia, tak że śmierć nie ma już nad nimi władzy. W ten sposób wciąż wieloznaczny termin $\mu \alpha \dot{o} \tau^{4} \varsigma^{44}$ odsłania swój kolejny wymiar, a nasze rozumienie go wzbogaca się o kolejne znaczenie. Świadek Chrystusa znaczy Świadek Życia - $\mu \alpha \dot{\alpha} \tau v \varsigma \tau \tilde{\eta} \varsigma \zeta \omega \tilde{\eta} \varsigma$.

\title{
MARTYRDOM AS A PARADOXICAL TESTIMONY OF LIFE IN THE ACTS AND PASSIONS OF THE CHRISTIAN MARTYRS
}

\author{
(Summary)
}

In ancient Christian literature (including the Acts of the Christian Martyrs), one can encounter many passages showing that the "eternal life" is not exactly the other life in the "world to come", but a reality in which the Christian already participates during worldly existence. If so, what is then the relation between this "eternal life," already a part of the martyr, and the "life on earth" that the martyr is just abandoning in such dramatic circumstances? It seems that there is a radical divergence between these two realities. The dialogues that the martyrs conduct with the members of "this world," while full of antitheses and antinomies, seem to confirm this apparent obviousness. Meanwhile, it is in these dialogues that a surprising rhetorical figure appears. The martyrs, instead of disputing, as it commonly occurred, the words of the representatives of "this world", literally repeat their postulates, therefore indicating themselves as those, who perfectly fulfill the pagan's meaning. The analysis of several dialogues in the Acts of the Christian Martyrs, in which this figure appears, and which can be called "paradoxical parallelism", shows that this figure is not only a rhetorical play of words, but also an intellectual figure, that establishes a complementary relation between "this world" and the salvation. Furthermore, it implicitly inscribes itself into the truth of the Revelation present throughout the entire Bible and explicitly in John 3,17 and 6,51. In this perspective, the martyr is not only a witness of the Truth, but also a witness of the life (zoe) that the world (kosmos) gets back from God.

44 Por. C. Noce, Il martirio. Testimonianza e spiritualità nei primi secoli, Roma 1987, 19: ,in certo senso, il titolo di martire come tale resta un enigma". 